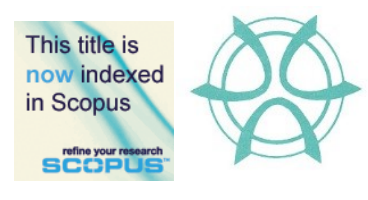

PLANNING MALAYSIA:

Journal of the Malaysian Institute of Planners

VOLUME 18 ISSUE 2 (2020), Page 193 - 205

\title{
STREET NETWORK DESIGN, PATTERN AND CHARACTERISTICS FOR MALAYSIAN LOCAL TOWN
}

\author{
Wan Saiful Nizam Wan Mohamad ${ }^{1}$, Ismail Said ${ }^{2}$, Khalilah Hassan ${ }^{3}$, Siti \\ Nurathirah Che Mohd Nasir ${ }^{4}$, Mohammad Rusdi Mohd Nasir ${ }^{5}$, Nor Iza \\ Syazwani Lokman ${ }^{6}$
}

\author{
1, 3, 4, 5, 6 Department of Landscape Architecture \\ Faculty of Architecture and Ekistics \\ UNIVERSITI MALAYSIA KELANTAN \\ ${ }^{2}$ Department of Landscape Architecture \\ Faculty of Built Environment and Surveying \\ UNIVERSITI TEKNOLOGI MALAYSIA
}

\begin{abstract}
A large number of local towns with compare to another type of town in Malaysia notifying the variety which required further identification to highlight a standard in planning on this town category. Hence, this paper aims to define the basic criteria for street network of Malaysia's local town. Pasir Puteh, Baling, Rembau and Pontian were selected based on the diversity of the street network structure develop from beginning to the modern era. The towns were mapped using land use data. This study employed comparative analysis to assess similarity and differences on the principles and term of street network system. The finding suggests that local towns founded before independence retain the historical value of the street system built by the colonizer and new zone of local town is to serve the community rather than the administration. Thus, the research on how street network in local town influence vehicle or pedestrian movement is recommended.
\end{abstract}

Keywords: Local town, street network, zoning characteristics, urban patterns, design criteria

\footnotetext{
${ }^{1}$ Senior Lecturer at Universiti Malaysia Kelantan. Email: saifulnizam@umk.edu.my
} 
Wan Saiful Nizam Wan Mohamad, Ismail Said, Khalilah Hassan, Siti Nurathirah Che Mohd Nasir, Mohammad Rusdi Mohd Nasir \& Nor Iza Syazwani Lokman

Street Network Design, Pattern, and Characteristic for Malaysian Local Town

\section{INTRODUCTION}

A local town describes as a place where people live and use it as a center for managing everyday needs (Ahmadi et al., 2009; Said and Wan Mohamad, 2017). In Malaysian history, settlement's center has been built by the leader of the state as an early colonization era. While, some urban street network used to collect natural resources, such as tin or rubber. For instance, street network in Taiping used to extract tin from the mining area to the town and then to Port Weld (Kuala Sepetang) by bus. After Independence, although the towns governed by the Malaysian state, the designs of the streets were still the same as the colonization period. This similarity is due to the structures of the towns affected by the colonizers. Before the $90 \mathrm{~s}$, in the era of colonization and after independence, towns thrive into a community center from a set of settlements and then become a town (Ramele et al., 2010; Harun and Jalil, 2012). At the start of the modernization period in the 1990s, the towns were built based on the National Physical Plan and established from a master plan such as Proton City, Perak (Salleh and Abdul Aziz, 2006). Thus, the history of urban development has explained the existence of a variety of street network structures in today's local towns.

Table 1: Types of towns in peninsular Malaysia

\begin{tabular}{cccc}
\hline $\begin{array}{c}\text { Types of } \\
\text { Town/City }\end{array}$ & $\begin{array}{c}\text { Population } \\
\text { Size }\end{array}$ & Examples of Town/City & $\begin{array}{c}\text { No. of } \\
\text { Town/City }\end{array}$ \\
\hline Global City & $\begin{array}{c}3.5 \text { million } \\
\text { and above }\end{array}$ & Kuala Lumpur, Putrajaya & 2 \\
\hline $\begin{array}{c}\text { Provincial } \\
\text { City }\end{array}$ & $\begin{array}{c}1.5 \text { to } 3.5 \\
\text { million }\end{array}$ & Georgetown, Johor Bahru, Kuantan & 3 \\
\hline State City & $\begin{array}{c}\text { No Minimum } \\
\text { Size }\end{array}$ & $\begin{array}{c}\text { Kuala Terengganu, Kota Bahru, } \\
\text { Alor Setar, Temerloh }\end{array}$ & 8 \\
\hline Main City & $\begin{array}{c}\text { More than } \\
100,000\end{array}$ & $\begin{array}{c}\text { Sungai Petani, Kulim, Taiping, } \\
\text { Shah Alam, Sepang }\end{array}$ & 47 \\
\hline Local Town & 10,001 to & Goping, Tapah, Kuala Kangsar, \\
& 100,000 & Banting, Kuala Pilah & 223 \\
\hline & \multicolumn{3}{c}{ Source: JPBD, 2016; Mansor, 2011; SPAD, 2012 }
\end{tabular}

Among other types of towns, local towns have the smallest population, ranging from 10,001 to 100,000 . Table 1 shows that Malaysia has 223 local towns, meaning that local towns have the highest number of towns in Malaysia, more than global city, provincial city, state city, and main city. Thus, with Malaysia's large number of local towns, the demand for study on this type of town is higher because the impact represents majority of towns in Malaysia. Besides, some studies on cities in Malaysia concentrate on urban morphology and historical values of the historic site of Malaysia such as Malacca and Georgetown (Ramele 
et al., 2010; Shamsuddin, 2011; Harun et al., 2013). Also, studies on the street network in cities are concentrated in major cities because of the rapid development of these types of towns (Moeinaddini et al., 2014). Thus, study on street network design, pattern, and characteristics is needed to understand local town as the dominant town for Malaysia. Therefore, this study aims to identify the street network criteria for Malaysia's local town consisting of zoning characteristics, street network design, and street network patterns. This study employed a depth study by Marshall (2005) in defining and understanding of the system and structure of street network in a town. The purpose of this study is to understand the characteristics as well as the structure of street network used to represent local town in Malaysia.

\section{Zoning Characteristics}

Towns in Malaysia were formed in the 1970s to the present in rapid development growth. Development experience shaped the physical of Malaysian local towns including the environment of the street network (Anwar et al., 2011; Mamat and Abdul Aziz, 2018; Mansor et al., 2012; Wan Mohamad \& Said, 2014). Studies of urban morphology have explained the formation of the physical characteristics of local towns now formed by the ruler's ideology for the towns (Ahmadi et al., 2009). This formation clarified the zoning created based on their characteristics in Malaysian local towns (Wan Mohamad \& Said, 2018). Harun and Jalil (2012) identified the three-stage development of towns in Malaysia during (i) the era of the Malay Sultanate, (ii) the era of colonialism, and (iii) the era of the Malaysian state. Accordingly, street network zoning characteristics in local towns are based on old zone physical identity (Malay Sultanate era and colonization era) and the new area (Malaysian government era).

\section{Street Network Design}

Street network design forms in the typology of $\mathrm{ABCD}$ pose the structure in complicated classification (Marshall, 2005). The design is used to characterize the street network type, involved street network patterns, design characters, and design history. For example, bilateral layout or B-type consists of two gridiron and parallel street network patterns. The design is developed when most people used to walk, carry (e.g. cattle car) and car (e.g. car, van, motorcycle and bus) to travel. Hermawan \& Ismiyati (2009) used the concept of ABCD typology to understand the development of Semarang City's street network. 
Wan Saiful Nizam Wan Mohamad, Ismail Said, Khalilah Hassan, Siti Nurathirah Che Mohd Nasir, Mohammad Rusdi Mohd Nasir \& Nor Iza Syazwani Lokman

Street Network Design, Pattern, and Characteristic for Malaysian Local Town

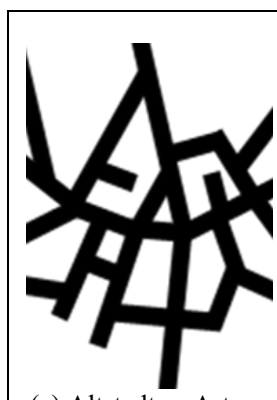

(a) Altstadt or A-type

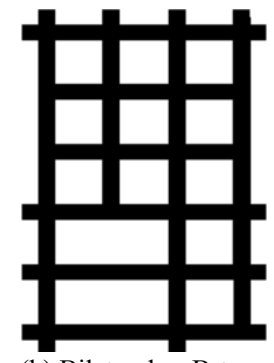

(b) Bilateral or B-type

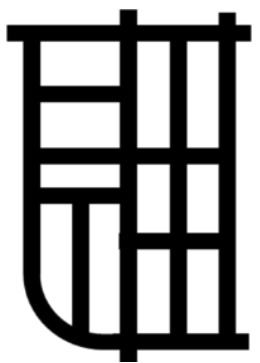

(c) Conjoint or C-type

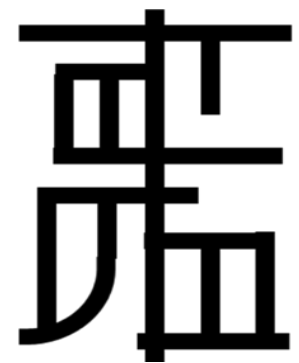

(d) Distributory or D-type

Figure 1: The form of street network design for ABCD typology principle

This study, therefore, used the typology of $\mathrm{ABCD}$ to be observed in defining the street network design in Malaysian local town. It involved A-type, B-type, Ctype, and D-type street networks (Figure 1). This selection is because the intricate distinction in defining model types can help this study to explore the outcomes of street network structure in Malaysia.

\section{Street Network Design}

Street connections in town have created different patterns of street networks that influence street connectivity. There are 32 studies from 1920 to 2001, as recorded by Marshall (2005), that used different definitions of types of street network patterns in urban planning, transportation system and engineering management.

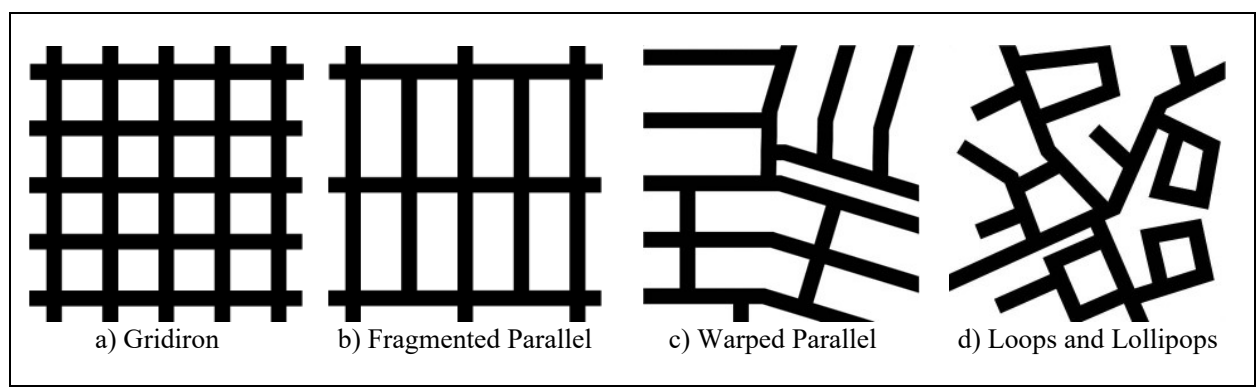

Figure 2: The types of street network pattern

Figure 2 trends such as gridiron, fragmented parallel, warped parallel, and loops and lollipops are correlated with affecting the frequency of walking, riding and transportation usage (Marshall and Garrick, 2011), death rates (Moeinaddini et al., 2014), and helping to define health care experiences (Marshall et al., 2014). Hence, this research used trends in defining the typology of street network patterns in local town as shown in Figure 2. 


\section{METHODOLOGY}

There are 223 local towns in Malaysia, according to Table 2. There are two groups of urban centers, major and minor (Mansor, 2011). The former has 30,001 to 100,000 inhabitants. The minor, however, has a smaller population of between 10,001 and 30,000. Therefore, four towns were selected for discussion to understand the street network of local towns. To represent the major settlement center, Pontian and Baling were chosen. Pasir Puteh and Rembau were chosen for the minor middle. Towns are chosen similarly to have a fair decision towards the towns for both types of urban centers. The four towns were selected because they have different street network styles. Depending on the period the town began to exist, the establishment of their street network; the period is according to the colonization era, independent era, and modernization era. Besides, there are different types of street network design and street network patterns in the street network in those towns.

Table 2: Type of Urban Center in Malaysian Local Town

\begin{tabular}{cccc}
\hline Urban Center & $\begin{array}{c}\text { Population } \\
\text { Size }\end{array}$ & Examples of Town & No. of Town \\
\hline Major & 30,001 to & Baling, Kuala Selangor, Kuala & 30 \\
Settlement & 100,000 & Pilah, and Jasin \\
Center & & Pasir Puteh, Rembau, Raub, & 193 \\
Minor & 10,001 to & Kuala Kangsar, and Kuala Perlis & \\
Settlement & 30,000 & \multicolumn{2}{c}{ Source: Mansor, 2011; SPAD, 2012 } \\
Center & & &
\end{tabular}

The land use data obtained from Jabatan Perancang Bandar dan Desa (JPBD) Semenanjung Malaysia was mapped to gather the information of town characteristics, structure of street network, and formation of streets. The data was categorized according to (a) zoning characteristics, (b) street network design, and (c) patterns of street network as variables for this study. From the mapping and categorization, the information of the selected towns was compared accordingly to define and identify the similarity and differences of the variables. Firstly, zoning characteristics of the towns was identified according to the physical character of the towns. Secondly, the street network design determined from mapping process based on the formation of the street network structure. Lastly, the patterns of street network were determined according to formation of streets connected with each other. This study employed comparative analysis to assess the similarities and differences of the variables identified in each town based on the principles suggested by Marshall (2005). The discussion is according to the interpretation of triangulations identified from the comparisons done for each 
Wan Saiful Nizam Wan Mohamad, Ismail Said, Khalilah Hassan, Siti Nurathirah Che Mohd Nasir, Mohammad Rusdi Mohd Nasir \& Nor Iza Syazwani Lokman

Street Network Design, Pattern, and Characteristic for Malaysian Local Town

selected town. The findings from selected towns, therefore, have the potential to show the identity of street network for local towns in Malaysia.

\section{RESULTS AND DISCUSSION}

The findings of this study discussed according to the variables of the criteria, which consist of zoning characteristics, street network design, and street network patterns.

\section{Zoning Characteristics of Malaysian Local Town}

Figure 3 shows the zoning of the physical character identified in four towns, (a) Pasir Puteh, Kelantan, (b) Baling, Kedah, (c) Rembau, Negeri Sembilan, and (d) Pontian, Johor.

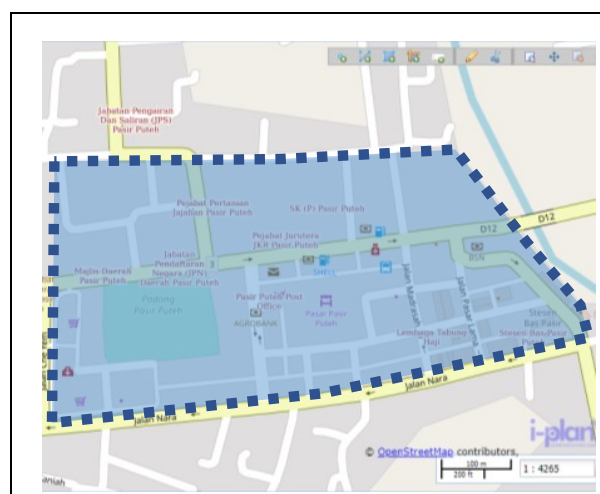

(a) Pasir Puteh, Kelantan

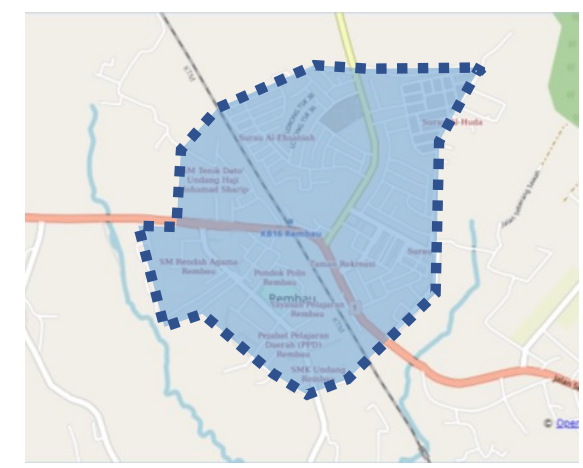

(c) Rembau, Negeri Sembilan

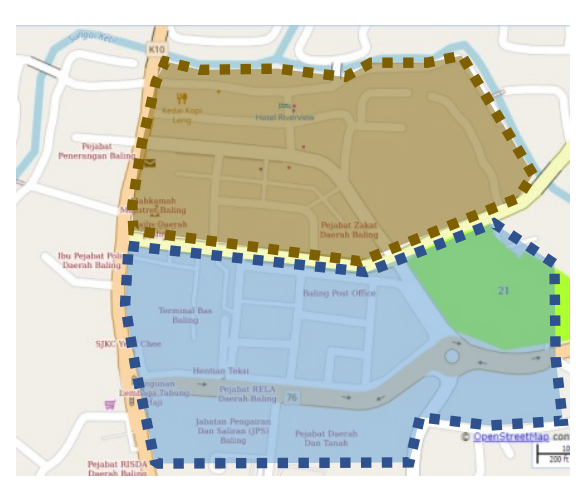

(b) Baling, Kedah

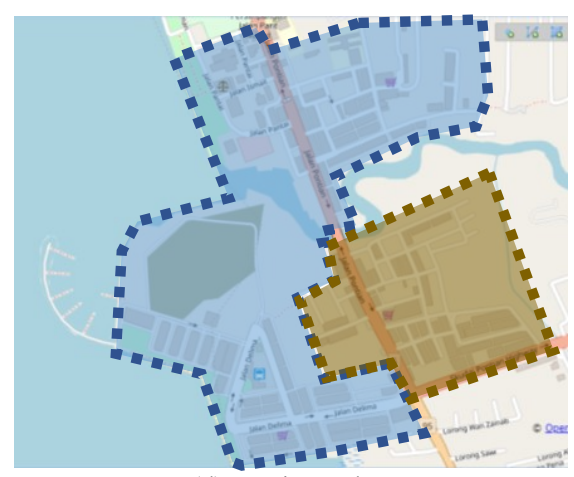

(d) Pontian, Johor

\section{Legend}

Old Town Characteristics - Old Zone

Modern Town Characteristics - New Zone

Figure 3: Town zoning of four selected local towns (2019) 
The town with physical characteristics is categorized as an old area, particularly the street network that formed before Independence. The character of street network designs and patterns was influenced by the grid and radial European street network styles. Besides, the Malaysian government preserves the environment of the old zone under the National Urbanization Policy II (JPBD, 2016). For example, while travelling on the street network, people in Baling, Kedah, can still experience the old façade of shophouses with art decoration on windows. In Pontian, Johor, the trees with high and significant character show the characteristic of the ascent of the old zone. Baling, Kedah's colonial buildings demarcated the colonial era history. Similarly, the towns that preserved and maintained under the National Urbanization Policy II (JPBD, 2016) shows the old area possesses its unique heritage, such as history, architecture, identity, and environment that shaped the characteristics of the street network.

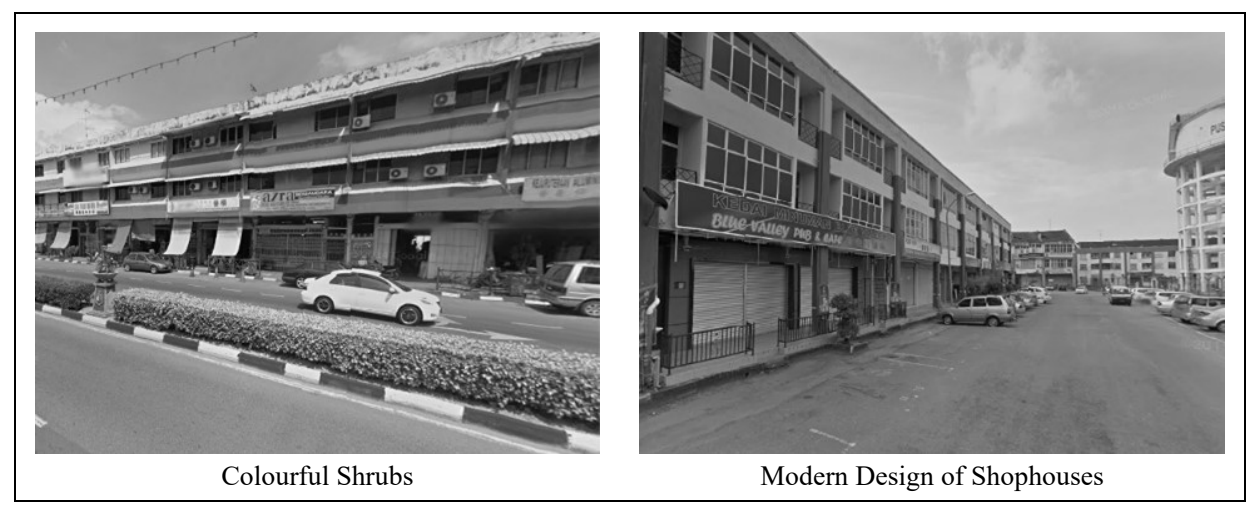

Figure 4: Environment of Pontian, Johor as the eco-tourism town in Malaysia (2017)

In the meantime, street network characteristics for the new zone are different. New zone is known as the town area that was established in 1957 after Malaysian Independence. Likewise, the town's development is focused on socioeconomic growth, such as industrial growth, education, and leisure. Therefore, the layouts and patterns influenced the characteristics of the street network for the new zone. The spatial layout of street characteristics used to achieve the town development theme. For example, Pontian, Johor is designated as an eco-tourism town by National Urbanization Policy II, is developed from a mixture of parallel patterns and loops. This street network shows that the pattern mix used to distinguish ways of pedestrian and transportation. For instance, according to the observation in Pontian Town, the environment of new zone is decorated with colourful shrubs like Eugenia oleina (Kelat Paya) and Ficus benjamina (Weeping Fig) to attract tourists. Moreover, the shophouses façade is built without art decoration with basic geometry to highlight the new face of tow with modern styles (Figure 4). The local towns, therefore, reflected by the physical 
Wan Saiful Nizam Wan Mohamad, Ismail Said, Khalilah Hassan, Siti Nurathirah Che Mohd Nasir, Mohammad Rusdi Mohd Nasir \& Nor Iza Syazwani Lokman

Street Network Design, Pattern, and Characteristic for Malaysian Local Town

characteristics of the old with different characteristics of the street network. During travel in Malaysian local towns, the variety of street network environment in old and new areas will optimize the representation of pedestrian actions.

\section{Street Network Design of Malaysian Local Town}

Table 3 shows three types of street network design identified from four selected towns, namely, bilateral (B-type), spousal (C-type) and distributor (D-type). The proposed street network for walking and carriage riding in Pasir Puteh also defines bilateral or B-type street network design. Walking in a grid shape, while walking on the streets, the layout provides four-way directions for the pedestrian. Whereas, street network design conjoint or C-type is a common type found at the town's expansion. This design is generally identified in new urban areas like Pontian and Rembau. The model was used in smoothing the traffic flow to support transport such as a car or bus. Finally, the layout of the street network with a hierarchical process is distributory or D-type. D-type design works in a hierarchy, collaborating with different types of streets, as opposed to B-type and C-type streets. In modern street networks, it is commonly found to differentiate the traffic flow depending on the particular area (Said and Wan Mohamad, 2017). Pontian Street, for example, is designed in Pontian as the main roads used to handle heavy traffic flow from other roads. Therefore, the model styles define the system in terms of travel mode, street hierarchy, and traffic flow to the street network in the towns. Therefore, in Table 3, the study of street network design for Pasir Puteh, Baling, Rembau and Pontian is provided in the identification of street network design for Malaysian town.

Table 3: Types of street network design in Malaysian local town

\begin{tabular}{lcccc}
\hline $\begin{array}{l}\text { Street Network } \\
\text { Design }\end{array}$ & Pasir Puteh & Baling & Rembau & Pontian \\
\hline Bilateral or B-type & $/$ & & & \\
\hline Conjoint or C-type & $/$ & $/$ & $/$ & $/$ \\
\hline Distributory or D-type & $/$ & $/$ & $/$ & $/$ \\
\hline
\end{tabular}

The street network design styles found in Pasir Puteh, Baling, Rembau and Pontian are shown in Table 3. In all four selected towns, namely C-type and D-type, there are two types of street network designs identified. This identification means that street network design in Malaysian local town was based on modern principles of urban planning that took into account the movement of pedestrians and the flow of transport which met the function of Ctype and D-type design. Relatively, local towns in Malaysia were rapidly developed during the transportation era, which was through the Malaysian National Plan, specifically after Malaysian Independence in 1957. Meanwhile, 
among the four selected towns, Pasir Puteh is the only town with B-type street network design. This B-type identification shows that there are local towns in Malaysia with B-type street network design where walking and carriage riding were built, which created four-way directions. B-type was only available in some local towns, particularly the towns that were established during the colonization period (1511 to 1957). The C-type and D-type are therefore required to represent Malaysia's street network. Meanwhile, in Malaysian local town, the town which includes B-type presents the distinctive design of the street network. The town with a B-type has the character of the old design that influences pedestrian preferences in finding a path in the town.

\section{Street Network Patterns of Malaysian Local Town}

The street network patterns identified in four selected local towns are shown in Table 4. In Pasir Puteh, Baling, Rembau, and Pontian, there are two types of street network patterns that are fragmented parallel patterns as well as patterns of loops and lollipops. This identification means that street network patterns are based on those patterns in Malaysian local town. However, from the trends, this shows that, while walking and automobiles were the fundamental transportation modes, Malaysian local towns were quickly developed after Malaysian Independence in 1957. This indication describes that the streets were arranged with hierarchy in Malaysian local towns where there are streets for vehicles, pedestrians, and a mix of pedestrians and vehicles. Pontian Street, for instance, is known in Pontian as the main road for movement of vehicles, while Pantai Street is defined as a local road for mixed-use of pedestrians and vehicles.

Table 4: Types of street network pattern in Malaysian local towns

\begin{tabular}{lcccc}
\hline $\begin{array}{l}\text { Street Network } \\
\text { Patterns }\end{array}$ & Pasir Puteh & Baling & Rembau & Pontian \\
\hline Gridiron & $/$ & & & \\
\hline Fragmented Parallel & $/$ & $/$ & $/$ & $/$ \\
\hline Warped Parallel & & $/$ & & $/$ \\
\hline Loops and Lollipops & $/$ & $/$ & $/$ & $/$ \\
\hline
\end{tabular}

Table 4 shows that Baling and Pontian are two local towns with warped parallel patterns. This indication shows that the trend is present only in local towns planned to follow the form of land area and current main roads. In Baling, at Liku Road, the twisted parallel patterns are created to fit the main road line that is Badlishah Street. In Pontian, to protect the green area, the warped parallel patterns were created at Medan Koop Road. Besides, Table 4 also reveals that Pasir Puteh is a local town with a gridiron pattern. This identification shows that the town area with a gridiron pattern was developed during the period when the 
Wan Saiful Nizam Wan Mohamad, Ismail Said, Khalilah Hassan, Siti Nurathirah Che Mohd Nasir, Mohammad Rusdi Mohd Nasir \& Nor Iza Syazwani Lokman

Street Network Design, Pattern, and Characteristic for Malaysian Local Town

primary mode of travel was walking and carriage. The street network is distinguished by the old area which formed during the colonial era. However, since the National Urbanization Policy II does not list Pasir Puteh as a historic town, the character of the old zone is not well preserved (JPBD, 2016). The characters of the old shophouses façade at Pasar Lama Road, for example, are unobtrusive because the state did not license the area. As a result, the towns protected by the National Urbanization Policy II as a historic town are required for the gridiron-like street network in order to maintain the character as unique (JPBD, 2016). Hence, fragmented parallel patterns, as well as loops and lollipops, are compulsory to represent Malaysian local towns ' street network. In the meantime, the town with twisted parallel and gridiron patterns is reflecting the street network that had the preferences to change as necessary and granting the opportunity to influence street connectivity.

\section{CONCLUSION}

The identity of a street network of a local town is defined according to the criteria from 223 local towns listed in Malaysian, including population, type of urban center, zoning characteristics, street network designs, and street network patterns. Therefore, the street network requirements representing local towns in Malaysia are listed in Table 5 .

Table 5: The criteria for street network of Malaysian local towns

\begin{tabular}{lll}
\hline Criteria & Components & Descriptions \\
\hline Population & 30,001 to 100,000 & $\begin{array}{l}\text { More population than minor } \\
\text { settlement center }\end{array}$ \\
\cline { 2 - 3 } & 10,001 to 30,000 & $\begin{array}{l}\text { Less population than major } \\
\text { settlement center }\end{array}$ \\
\hline Types of Urban \\
Center & Major Settlement Center & Consist of two sets of boundaries \\
\cline { 2 - 3 } $\begin{array}{l}\text { Zoning } \\
\text { Characteristics }\end{array}$ & Minor Settlement Center & Consist of single set of boundary \\
\cline { 2 - 3 } & Old Zone & $\begin{array}{l}\text { Preserved area by NUP 2 2016 as } \\
\text { historic town }\end{array}$ \\
\hline Street Network & B-Type & $\begin{array}{l}\text { Area in the town developed after } \\
\text { Malaysian Independence in 1957 }\end{array}$ \\
\cline { 2 - 3 } Designs & C-Type & Identified in local town \\
\cline { 2 - 3 } & D-Type & Identified in local town \\
\hline Street Network & Gridiron & Identified in local town \\
\cline { 2 - 3 } Patterns & Fragmented Parallel & Identified in local town \\
\cline { 2 - 3 } & Warped Parallel & Identified in local town \\
\cline { 2 - 3 } & &
\end{tabular}


Based on the criteria shown in Table 5 , understanding the identity of a street network for the local towns in Malaysia is evaluated. Local town population includes categories (a) 10,001 to 30,000 and (b) 30,001 to 100,000 leading to categorization of urban center type as either major settlement center or large settlement center. The physical characteristics create a town classification that only refers to a community that has an old and new area or a new zone. In particular, the town's old neighbourhood is protected and preserved as heritage towns under the National Urbanization Policy II (JPBD, 2016). Though, after Malaysian Independence in 1957, the town included as a new area is rapidly developing. Street network of Malaysian local town has advantages on designs because it has B-type, C-type and D-type layout. The street network patterns identified which are gridiron, fragmented parallel, warped parallel, as well as loops and lollipops represent the local town developed in the era according to different types of transport mode.

The discrepancies between two zoning features that are old and new areas in a town suggest an interpretation of a street network's identity portrays the local town's streetscape. The variety of street network layouts and street network patterns means that eliciting street network communication leads to the street network architecture system of local town. This research, therefore, demonstrates the importance of street network parameters in the field of urban planning to the fields of urban landscape design, architecture science, social behaviour, and environmental psychology. Accordingly, this study contributes to future research on how human behaviour that reflected from the criteria of street network in Malaysian local town.

\section{ACKNOWLEDGEMENTS}

The Ministry of Education Malaysia funds this study under Fundamental Research Grant Scheme, FRGS (Research Code: FRGS/1/2018/SSI11/UMK/03/1, R/FRGS/A1200/01672A/002/2018/00552).

\section{REFERENCES}

Ahmadi, V., Farkisch, H., Irfan, A., Surat, M., \& Zain, M. F. M. (2009). A theoretical base for urban morphology: practical way to achive the city character. Journal of Social Sciences and Humanities, 4(1), 30-39.

Anwar, W. F. F., Said, I., Ossen, D. R., \& Rasyidi, M. H. (2011). Method to elicit local wisdom in perceiving the transformation of historical living environment. Journal of RUAS, 11-22. 
Wan Saiful Nizam Wan Mohamad, Ismail Said, Khalilah Hassan, Siti Nurathirah Che Mohd Nasir,

Mohammad Rusdi Mohd Nasir \& Nor Iza Syazwani Lokman

Street Network Design, Pattern, and Characteristic for Malaysian Local Town

Harun, N. Z., \& Jalil, R. A. J. (2012). The morphological history of the malaysian urban form. International Proceedings of Economics Development and Research, 48(24), 111-116.

Harun, N. Z., Mansor, M., \& Said, I. (2013). The Experience of Diversity in Open Spaces of Two Historical Towns in Malaysia. Procedia - Social and Behavioral Sciences, $85,582-591$.

Hermawan, F., \& Ismiyati. (2009). The density, road network pattern identification and isoprice perspectives. In International Conference on Sustainable Infrastructure and Built Environment in Developing Countries. Bandung, West Java, Indonesia.

Jabatan Perancangan Bandar dan Desa (JPBD) (2016). National Urbanization Policy II: Federal Department of Town and Country Planning Peninsular Malaysia.

Mamat, M. J., \& Abdul Aziz, M. F. (2018). Early town planning system of small towns in Perak. Journal of the Malaysian Institute of Planners. 16(4), 55-67.

Mansor, M. (2011). Experiential contacts of residents with green infrastructure network in Taiping. (Doctor Philosophy), Universiti Teknologi Malaysia.

Mansor, M., Said, I., \& Mohamad, I. (2012). Experiential Contacts with Green Infrastructure's Diversity and Well-being of Urban Community. Procedia - Social and Behavioral Sciences, 49, 257-267.

Marshall, S. (2005). Street and Patterns: Spon Press.

Marshall, W. E., \& Garrick, N. W. (2011). Does street network design affect traffic safety? Accid Anal Prev, 43(3), 769-781.

Marshall, W. E., Piatkowski, D. P., \& Garrick, N. W. (2014). Community design, street networks, and public health. Journal of Transport \& Health, 06.

Moeinaddini, M., Asadi-Shekari, Z., \& Zaly Shah, M. (2014). The relationship between urban street networks and the number of transport fatalities at the city level. Safety Science, 62, 114-120.

Ramele, R., Isnin, Z., \& Jabar, I. L. (2010). Urban morphology of buffer zone and its survival in the historical city of Malacca. Journal of Built Environmental, 7(1), $35-41$.

Said, I., \& Wan Mohamad, W. S. N. (2017). Differences of sreet connectivity between old and new Zone in Malaysian small town. International Journal on Advanced Science, Engineering and Information Technology, 7(4), 1464-1470.

Salleh, D., \& Abdul Aziz, A. R. (2006). Konsep Pembangunan Bandar Baru Dalam Pembangunan Wilayah. In Kepelbagaian Isu Dalam Pentadbiran dan Pembangunan di Malaysia (pp. 66-80): Penerbit Universiti Utara Malaysia, Sintok.

Shamsuddin, S. (2011). Townscape Revisited: Unravelling the Character of the Historic: UTM Press.

Suruhanjaya Pengangkutan Awam Darat (SPAD) (2012). National land public transport masterplan. Malaysia: Land Public Transport Comission.

Wan Mohamad, W. S. N., \& Said, I. (2014). A review of variables of urban street connectivity for spatial connection. IOP Conference Series: Earth and Environmental Science, 18. 
Wan Mohamad, W. S. N., \& Said, I. (2018). Familiarity factors of street features in pedestrian wayfindings. International Journal of Built Environment and Sustainability, 5(3), 201-207.

Received: January 2020. Accepted: $1^{\text {st }}$ April 2020 